\title{
THE IMPACT OF ORGANIZATIONAL CULTURE AND SENSATION SEEKING ON EMPLOYEE PERFORMANCE WITH CREATIVITY AS A MEDIATING VARIABLE: A STUDY AT WEST NUSA TENGGARA PROVINCIAL HEALTH OFFICE
}

\author{
Yuniwati Vonny lka \\ Department of Human Resource Development, Postgraduate School, \\ University of Airlangga, Indonesia \\ E-mail: vonnyikayuniwati@gmail.com
}

\begin{abstract}
This purpose of this study is to analyze and obtain empirical evidence relating to the influence of organizational culture and sensation seeking on employee performance. And also to discover whether creativity mediates organizational culture and sensation seeking towards employee performance. The subjects of this study were employees of the Health Office of the Province of West Nusa Tenggara. This research is explanatory research with the number of respondents as many as 109 people. The data collection method used in this study was through a survey using a questionnaire. The data analysis technique used in this study is the Structural Equation Modeling-Partial Least Square (SEM-PLS) technique. The results of this study indicate that: 1) Organizational Culture has a significant effect towards Employee Performance, 2) Sensation Seeking has a significant effect towards Employee Performance, 3) Organizational Culture has a significant effect towards Creativity, 4) Sensation Seeking has a significant effect towards Creativity, 5) Creativity has a significant effect towards Employee Performance.
\end{abstract}

\section{KEY WORDS}

Organizational culture, sensation seeking, creativity, employee performance.

Improving the performance of employees or the State Civil Apparatus will directly improve organizational performance which will ultimately improve the image of public organizations in particular and the government in general. In the assessment of the integrity survey of the Government Agency Performance Accountability System (GAPAS) by the Ministry of Administrative Reform and Bureaucratic Reform of Indonesian Republic on the performance of the State Civil Apparatus in West Nusa Tenggara Province on 23 October 2017, West Nusa Tenggara Province GAPAS is still B (class 60-70) after the previous year always gets a CC score (grades 50-60), which means that repairs need to be done. The results of the West Nusa Tenggara Provincial Health Office performance are seen in line with the results of the integrity survey of the Government Agency Performance Accountability System (GAPAS) conducted by the Ministry of Administrative Reform and Bureaucratic Reform of Indonesian Republic that the performance results are not optimal. So it needs to be explored further about the factors that can affect performance improvements in regional services. Creativity has been predicted as one of the factors that can explain significant performance improvements (Amabile, Scahtzel, Moneta and Kramer, 2004; Yang and Choi, 2009; Wu et al., 2012; Lee \& Tan, 2012; and Indrasari et al., 2016). Besides organizational culture (Ahmed \& Shafiq, 2012; and Darsana, 2013) and personality factors (Barrick \& Mount, 1991; Skyrme et al., 2005: Rose et al., 2010) also predictors as factors that can affect employee performance.

\section{LITERATURE REVIEW}

Organizational culture is defined as shared values and beliefs that are believed by individuals in the organization and determine how they perceive, think, and react to various environments (Kreitner and Kinicki, 2012). Organizational culture is related to economic performance and organizational success (Denison \& Mishra, 1995; Pothukuchi et al., 2002; 
Sorensen, 2002). Kotter and Heskett (1992) state that strong organizational culture has an impact that greatly affects individuals and the performance and work performance of the organization as a whole. Daniel R. Denison (2000) suggests a model that focuses on the extent to which employees know their vision and mission, the extent to which employees think that organizations have values, processes, and systems that are in line with the goals of the company or organization and the extent to which employees are involved in moving the organization in achieving its goals. Denison characterizes the reciprocal influence of four cultural factors or four traits that affect organizational effectiveness and each of the four traits has three index variables: involvement, consistency, adaptability, and mission. Involvement is a situation where employees feel that their activities are closely related to the goals of the organization, that they have been empowered, that teamwork must be valued and priority given to the development of employee capabilities. Involvement is characterized by indices such as Empowerment, Team Orientation, and Capability Development. Consistency is a high level of integration and coordination. Consistency is characterized by the Core values, Agreement, Coordination, and Integration index. Adaptability is a state within a frame that flexibly responds to organizational requirements of customers, takes risks, learns from their own mistakes and is ready for the change. Adaptability is characterized by Creating Change, Customer Focus, and Organizational Learning index. The Mission is the characterization of the goals and direction of the organization from strategic development, based on concepts that have been developed by the organization and are future-oriented. The mission is characterized by an index of Strategic Direction and Intent, Goals and Objectives, Vision.

Sensation seeking is a basic need, but sometimes it is not realized. Zuckerman (1994a, p.27) defines sensation seeking as a biosocial trait, namely the desire or desire to seek varied, new, complex experiences and intense sensations, as well as willingness to take physical, social, legal and financial risks to be able to experience these experiences and sensations. Sensation seekers according to Jackson $(2005,2008)$ are individuals who have interest, curiosity, and exploration while according to Zuckerman sensation seekers are individual risk takers. Jackson focuses on learning elements from sensation seeking inspired by experimental research Ball and Zuckerman $(1990,1992)$ and Pickering (2004) which show the possibility of successful sensation seeker learning. Jackson $(2005,2008 a)$ argues that sensation seekers have an intrinsic desire to explore the environment that will lead them to create a large number of exploration experiences that can result in one functional or beneficial outcome or dysfunctional outcome. Jackson $(2005,2008,2009)$ designed a hybrid model of learning in Personality (HMLP), namely combining sensation seeking as a psychobiological construct in a learning model in personality (learning in personality) to be able to understand sensation seeking as predictors of various functional and dysfunctional work results. According to the Jackson model, sensation seeking is seen as a primitive drive that needs to be expressed through sophisticated social cognitive mechanisms to make sensation seeking the basis for functional learning. Sensation seekers are characterized as individuals with explorative, impulsive, seize the moment tendencies, openness to experience, opportunistic and risk takers.

Creativity is defined by Amabile et al. (1996) as a new and appropriate solution for completing open tasks. Csikszentmihalyi and Wolfe (2005) see creativity as an original idea or product, valued and implemented. Barry and Kanematsu (2006) define creativity as the ability to produce original ideas and new things, which also involve combinations of current work, objects, and ideas in various ways for new purposes. Teresa M. Amabile (1983) in Kozbelt et al., (2010) introduced the theory of creativity and innovation called The Componential Model of Individual Creativity. This model states that each individual needs three individual or internal components to generate individual creativity. 1) Domain-relevant skills, 2) Creativity-relevant skills, 3) Intrinsic Task motivation.

Performance is defined as the record of outcomes produced on a specified job function or activity during a time period (Bernardin and Russel, 1998). Definition of job performance or performance is the behavior or activity carried out by employees when working directed to the goals and objectives of the organization (Motowidlo et al., 1997). Dessler (2009) argues: work performance of employees is the actual performance of employees compared to the 
expected performance of employees. Mathis and Jackson (2010) stated that the measurement of employee performance can be associated with what is done and what is not done by employees related to 1) Quantity of Output, 2) Quality of Output, 3) Timeliness of Output, 4) Presence/Attendance On The Job, 5) Efficiency of Work Completed, 6) Effectiveness of Work Completed.

\section{METHODS OF RESEARCH}

This research is explanatory quantitative research that uses the population in the West Nusa Tenggara Provincial Health Office Sampling is done by the Proportional Stratified Random Sampling technique, which is 109 employees. Data was collected using a questionnaire. The measurement items are stated in a Likert scale statement, with a range of scores between 1 and 5 . The study variables consist of independent variable Organizational Culture (X1), Sensation Seeking (X2), Creativity mediation variable (Y) and Employee Performance dependent variable $(Z)$. The data analysis technique uses Structural Equation Modeling-Partial Least Square (SEM-PLS) techniques with the analysis tools used by WarpPLS version 5.0.

The research framework is presented in Figure 1.

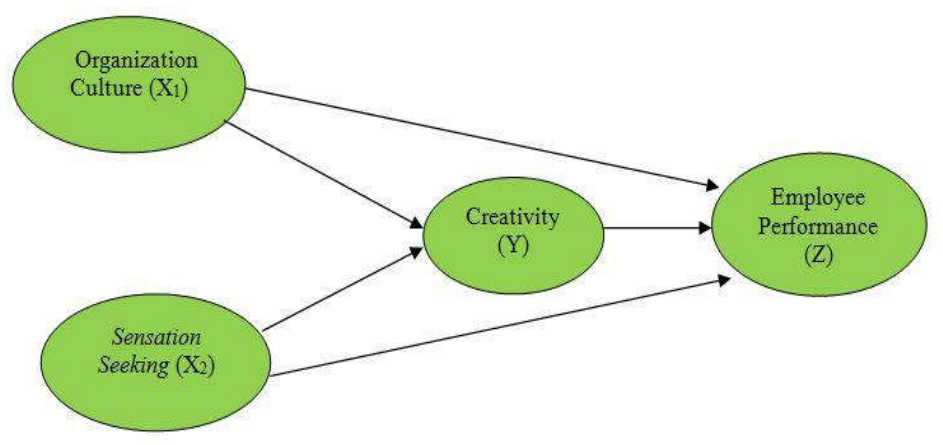

Figure 1 - Research Framework

Hypotheses:

H1: Organizational Culture has a significant effect on Employee Performance;

$\mathrm{H} 2$ : Sensation Seeking has a significant effect on Employee Performance;

H3: Organizational Culture has a significant effect on Creativity;

$\mathrm{H} 4$ : Sensation Seeking has a significant effect on Creativity;

H5: Creativity has a significant effect on Employee Performance.

\section{RESULTS AND DISCUSSION}

To measure organizational culture variables refers to Denison's (2000) organizational culture model which is reflected by 12 indicators developed into 24 sub-indicators. Measurement of sensation seeking variables refers to Jackson's (2005) sensation seeking model which is reflected by 6 indicators developed into 15 sub-indicators. The measurement of creativity variable refers to Amabile's creativity (1983) which is reflected by 3 indicators developed into 6 sub-indicators. Measurement of performance variables refers to the performance model of Mathis \& Jackson (2010) which is reflected by 6 indicators developed into 13 sub-indicators. So that there are a total of 58 statements in the questionnaire. This study uses the Structural Equation Model (SEM) data analysis technique with the Partial Least Square (PLS) analysis model with the analysis tool used by WarpPLS version 5.0.

The outer model analysis is done to ensure that the measurements used are feasible to be used as measurements (valid and reliable). To test the validity of the questionnaire used Discriminant Validity is measured by comparing the average root square value of each construct with the correlation between other constructs in the model. The value of Average 
Variance Extracted (AVE) must be greater than 0.5 with a p-value smaller than the significance level (Latan and Ghozali, 2014).

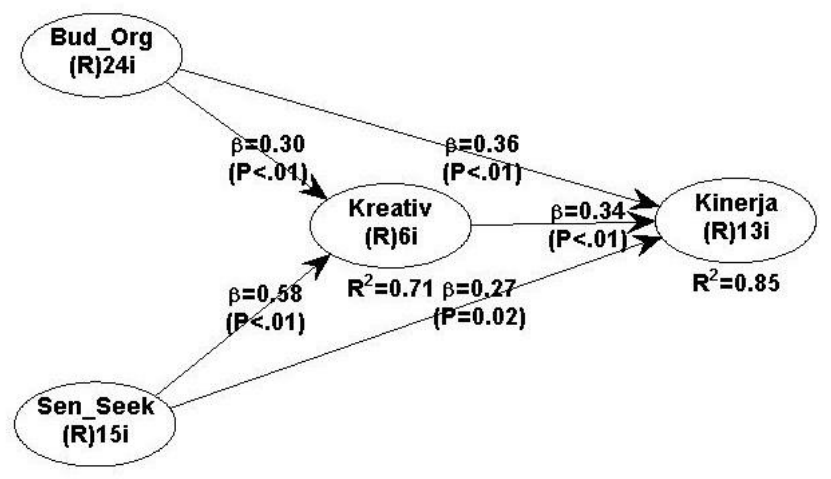

Figure 2 - Results of Model

Table 1 - AVE Measurement

\begin{tabular}{|c|c|c|c|c|}
\hline Variable & Organizational Culture & Sensation Seeking & Creativity & Employee Performance \\
\hline AVE & 0.503 & 0.523 & 0.612 & 0.606 \\
\hline
\end{tabular}

It can be seen on table 1 that all results of discriminant validity are above 0.5 so fulfill the reliability of internal consistency, all variables are said to be valid and can provide confidence. After passing the validity test then the reliability test is performed with the composite reliability technique. The reliability coefficient must be greater than 0.7 . The measurement results of composite reliability in this study can be seen in the following table:

Table 2 - Measurement Reliability

\begin{tabular}{|c|c|c|}
\hline Variable & Composite Reliability & Cronbach's Alpha \\
\hline Organizational Culture & 0.960 & 0.960 \\
\hline Sensation Seeking & 0.942 & 0.934 \\
\hline Creativity & 0.904 & 0.871 \\
\hline Employee Performance & 0.952 & 0.945 \\
\hline
\end{tabular}

Based on Table 2 above it can be seen that the entire proceeds from composite reliability or the regression coefficients for all variables are above 0.7 as well as the Cronbach Alpha values are all also above 0.70 so that they meet the reliability of internal consistency and all these variables are said to be reliable.

The inner model analysis or structural analysis of the model is carried out to ensure that the structural models are robust and accurate. Evaluation of inner models can be seen from several indicators which include: 1. Determination coefficient (R2), 2. Predictive Relevance (Q2). This measurement examines the influence between variables using adjusted $\mathrm{R}$ Square which is classified into a model. The influence between variables in the system built on the study was calculated using predictive relevance aimed at assessing the effective validity of independent variables with the following results:

Table 3 - R-square value Adjusted (Adjusted $\mathrm{R}^{2}$ )

\begin{tabular}{|c|c|c|}
\hline Endogenous Variables & Value of $R$-Square Adjusted (Adjusted R ${ }^{2}$ ) & Q-square (Q2) \\
\hline Creativity & 0.701 & 0.704 \\
\hline Employee Performance & 0.841 & 0.841 \\
\hline
\end{tabular}

It can be seen on table 3 that creativity has Adjusted R-square value (adjusted $R^{2}$ ) of $0.701(70.1 \%)$. This shows that the creativity variable can be predicted by organizational culture variables, and sensation seeking is $70.1 \%$. While the remaining $29.9 \%$ can be predicted by other variables outside the model or variables not used in this study. 
Furthermore, that performance has Adjusted R-square value (adjusted $\mathrm{R}^{2}$ ) of $0.841(84.1 \%)$. This shows that the performance variable can be predicted by variable organizational culture, sensation seeking and creativity by $84.1 \%$. While the remaining $15.9 \%$ can be predicted by other variables outside the model or variables that are not used in this study. To see the relationship of all variables in the system built in this study, the value of $Q^{2}$ is found in the range $Q^{2} \geq 0.7$.

The output of the PLS software proves the main hypothesis and the sub-hypotheses of the research, which are shown in table 4.

Table 4 - The Investigation of the Research Hypotheses

\begin{tabular}{|c|c|c|}
\hline Hypotheses & Original Sample & P Values \\
\hline Organizational Culture >> Employee Performance & 0,363 & 0,001 \\
\hline Sensation Seeking >> Employee Performance & 0,269 & 0,002 \\
\hline Organizational Culture >> Creativity & 0,301 & 0,001 \\
\hline Sensation Seeking >> Creativity & 0,580 & 0,001 \\
\hline Creativity >> Employee Performance & 0,338 & 0,001 \\
\hline
\end{tabular}

Hypothesis 1 stated that Organizational Culture $\left(X_{1}\right)$ has a significant effect on Employee Performance $(Z)$. The statistical test results found the value of $p$-values of 0.001 were $<0.1$ and the estimated value of the regression coefficient (original sample) produced is equal to 0.363 . The positive sign in the regression coefficient shows a unidirectional relationship between organizational culture and performance where if the organizational culture increases once, the performance increases by 0.363 times. It can be concluded that the data supports the $\mathrm{H} 1$ hypothesis where there is a significant and positive relationship between organizational culture and employee performance at the West Nusa Tenggara Provincial Health Office. The results of this study are in line with the research conducted by the research conducted by Ahmed \& Shafiq (2012) and Darsana (2013) showing that there is a significant relationship that occurs between organizational culture and organizational performance or effectiveness. Strong organizational culture will help organizations to provide certainty to all employees to develop together, grow and develop agencies or organizations. Employees who already understand the overall values of the organization will make these values an organizational personality. These values and beliefs will be manifested into their daily behavior at work so that they will become individual performance and in turn will become organizational performance.

Hypothesis 2 stated that Sensation Seeking $\left(X_{2}\right)$ significantly influence Employee Performance $(Z)$. The results of statistical tests find the value of $p$-values at 0.002 were $<0.1$ and the estimated value of the regression coefficient (original sample) produced is equal to 0.269 . The positive sign in the regression coefficient shows a unidirectional relationship between sensation seeking and performance where if sensation seeking increases once, the performance increases by 0.269 times. It can be concluded that the data supports the $\mathrm{H} 2$ hypothesis where there is a significant and positive relationship between sensation seeking and employee performance at the West Nusa Tenggara Provincial Health Office. The results of this study are in line with research conducted by Mustika and Jackson (2016), Donohew et al., 2000, Sunder et al., (2017), they found that sensation seeking personality factors can affect performance or job performance. Sunder et al., (2017), who in his research found that sensation seekers tended to accept or have innovation and change. Organizations supported by individual sensation seekers are able to produce more patent products with greater market impact because individuals with these types of characteristics will usually increase the effectiveness of innovation and pursue more diverse and original projects. Openness to new ideas and the willingness to pursue new methods in work overrides their desire to maintain a structured and repetitive situation. They also become innovative consumers, not afraid to try new things and always know alternatives. With the support of characteristics like this in organizations that require a high level of innovation, it can direct the organization to success. 
Hypothesis 3 stated that Organizational Culture $\left(X_{1}\right)$ significantly influence Creativity $(Y)$. The statistical test results found the value of $p$-values of 0.001 were $<0.1$ and the estimated value of the regression coefficient (original sample) produced is equal to 0.301 . The positive sign in the regression coefficient shows a unidirectional relationship between organizational culture and performance where if the organizational culture increases once, the performance increases by 0.301 times. It can be concluded that the data supports the $\mathrm{H} 3$ hypothesis where there is a significant and positive relationship between organizational culture and creativity. The results of this study are in line with research conducted by Castiglione (2008), Keskin, (2009), Valencia et al., (2010), Hirst et al., (2011), Karamipour et al., (2015) and Ali Taha et al., (2016). Keskin (2009) found that organizational culture can be used to support and develop creativity and innovation. Castiglione (2008) states that a place for developing the potential capacity of individual creativity will emerge when organizational culture accepts it. Individuals will behave creatively if the culture in the individual's environment can encourage individuals to get new ideas. Specifically, this study found a relationship between the alignment of employee's personal values and organizational cultural values and the willingness of employees to generate new ideas.

Hypothesis 4 stated that Sensation Seeking $\left(\mathrm{X}_{2}\right)$ significantly influence Creativity $(\mathrm{Y})$. The statistical test results found the value of $p$-values of 0.001 where $<0.1$ and the estimated value of the regression coefficient (original sample) produced was equal to 0.580 . The positive sign in the regression coefficient shows a unidirectional relationship between sensation seeking and creativity where if sensation seeking increases once, creativity increases by 0.580 times. It can be concluded that the data supports the $\mathrm{H} 4$ hypothesis where there is a significant and positive relationship between sensation seeking and creativity. The results of this study are in line with research conducted by Amabile and Gryskiewicz (1987) stating that things, quality or individual components that can encourage the emergence of creativity to include the diversity of personality traits, while the quality or individual components can hinder or prevent the emergence of creativity, among others, is not motivated. Another supporting study conducted by Dewwet (2007) who found that antecedents or things that precede employee creativity are intrinsic interests in one's work and the influence of intrinsic motivation on creativity transmitted through increased willingness to take risks.

Hypothesis 5 stated that Creativity $(Y)$ significantly influence Employee Performance $(Z)$. The statistical test results found the value of $p$-values of 0.001 were $<0.1$ and the estimated value of the regression coefficient (original sample) produced is equal to 0.338 . A positive sign on the regression coefficient shows a unidirectional relationship between creativity and performance where if creativity increases once, the performance increases by 0.338 times. It can be concluded that the data support the hypothesis $\mathrm{H} 5$ where there is a significant and positive relationship between creativity and performance. The results of this study are in line with the research conducted by Yang and Choi (2009) who found that creativity is a predictor to explain significant team performance improvements. Furthermore Lee \& Tan (2012), Wu et al. (2012), and Indrasari et al. (2016) from the results of his research found that personal or individual creativity can improve task performance and group performance. Creativity results from the accumulation of individual thinking skills and skills derived from formal education and their past experience. The creative response involves thinking about new procedures or processes to work on a task or work to complete work or identify products or services to better meet customer needs. This also involves improving existing procedures or processes to increase efficiency or to find more effective procedures or processes.

Table 5 - Indirect Effect

\begin{tabular}{|l|c|c|c|}
\hline \multicolumn{1}{|c|}{$\mathrm{n} / \mathrm{n}$} & Indirect Effects & P-Value & VAF \\
\hline $\begin{array}{l}\text { Organizational Culture Influences Employee Performance } \\
\text { Mediating by Creativity }\end{array}$ & 0.447 & $<0.001$ & 0.737 \\
\hline $\begin{array}{l}\text { Sensation Seeking Influences Employee Performance } \\
\text { Mediating by Creativity }\end{array}$ & 0.367 & $<0.001$ & 0.551 \\
\hline
\end{tabular}


It was found that: First, the results of mediation calculations that Variance Accounted For (VAF) amounting to 0.737 and with P-Value, $p<0.01$, it can be concluded that the VAF value is categorized as partial mediation and the effect is positive and significant. This shows that a strong organizational culture will have an impact on the formation of employee performance and also shape creativity and ultimately improve employee performance at the West Nusa Tenggara Provincial Health Office;

Second, the mediation calculation results that the VAF value is 0.551 and with P-Value $p<0.01$, it can be concluded that the VAF value is categorized as partial mediation and the effect is positive and significant. This shows that sensation seeking will have an impact on employee performance and also shape creativity and ultimately improve the performance of employees of the West Nusa Tenggara Provincial Health Office.

\section{CONCLUSION}

The conclusion of this study is that there is a positive and significant influence of organizational culture on employee performance at the West Nusa Tenggara Provincial Health Office. It can be concluded that a strong or weak organizational culture will have an impact on employee performance. The higher or stronger the value of organizational culture, the higher the performance of employees, the decline in organizational cultural values will reduce employee performance. There is a positive and significant influence between sensation seeking towards the performance of employees of the West Nusa Tenggara Provincial Health Office. It can be concluded that high or low levels of sensation seeking will affect employee performance. The higher the level of sensation seeking, the higher the level of employee performance and vice versa. There is a positive and significant influence between organizational culture on creativity. It can be concluded that organizational culture is one factor that can encourage the level of employee creativity. The stronger the organizational culture, the higher the level of creativity of employees and vice versa. There is a positive and significant influence between sensation seeking towards creativity. It can be concluded that high or low levels of sensation seeking will affect employee creativity. The higher the level of sensation seeking, the higher the level of creativity of employees and vice versa. There is a positive and significant influence between creativity on the performance of employees of the West Nusa Tenggara Provincial Health Office. It can be concluded that a high or low level of creativity will affect employee performance. The higher the level of creativity, the higher the employee's performance, the decrease in the level of employee creativity will have an impact on the decline in employee performance at the West Nusa Tenggara Provincial Health Office.

Found in organizational culture variables that indicator involvement, consistency, adaptability, and mission are in line with the expectations of the respondents. Also found the highest score is found in the empowerment index, while the lowest score is found in the index agreement. Therefore it is necessary to increase the ability of employees to reach agreement on important issues and agreements and the ability to reconcile in the face of problems that arise due to differences between them. The sensation seeking variable found that the Openness to Experience indicator had the highest score, while the lowest score was found on the Risk Taker indicator. This explains that personality traits can predict what the individual "will do" rather than just what he "can do", therefore management needs to be better able to understand and manage differences in values and needs of employees in terms of curiosity and exploration and guide the trait in such a way that the individual expresses again or re-expresses his curiosity and exploration through a positive way for them and the community. Furthermore, in the creativity variable, it was found that the indicators Domain-relevant skills, Creativity-relevant skills, and Intrinsic Task motivation were in line with the expectations of respondents. Found the highest score found in the Creativityrelevant Skills indicator, the Domain-relevant Skills score has the lowest score but the scores of Creativity-relevant Skills, Task Motivation, and Domain-relevant Skills indicators are in the high category. Management can encourage and support employees to generate ideas, look for new ways to complete their work efficiently and provide confidence in the ability of 
employees to solve problems. The next finding on the performance variable is found that the Quality of output indicator has the highest score; while the lowest score value is on the Efficiency of work completed indicator. However, overall scores on employee performance indicators are in the high category. This means that the variable employee performance indicators are in line with the expectations of respondents.

\section{REFERENCES}

1. Ahmed, M., \& Shafiq, S. (2014). The Impact of Organizational Culture on Organizational Performance: A Case Study of Telecom Sector. Global Journal of Management and Business Research: A Administration and Management, 13(3).

2. Ali Taha, V., Sirkova, M., \& Ferencova, M. (2016). The Impact Of Organizational Culture On Creativity And Innovation. Polish Journal Of Management Studies, 14(1).

3. Amabile, TM (1996). Creativity in Context. Boulder, CO: Westview.

4. Amabile, TM, \& Gryskiewicz, SS (1987). Creativity in the R \& D laboratory. Technical Report Number 30. Greensboro, NC

5. Amabile, TM, Schatzel, Elizabeth A., Moneta, GB, \& Kramer, SJ (2004). Leader behaviors and the work environment for creativity: Perceived leader support. The Leadership Quarterly, 15(1), 5-32.

6. Ball, SA, \& Zuckerman, M. (1990). Sensation seeking, Eysenck's personality dimensions and reinforcement sensitivity in concept formation. Personality and Individual Differences, 11, 343-353.

7. Barrick, MB, \& Mount, MK (1991). The big five personality dimensions and job performance: A meta-analysis. Personnel Psychology, 44(1), 1-26.

8. Bernardin, HJ, \& Russel, JEA (1998). Human resource management: An experimental approach. New York: McGraw-Hill Companies. Inc.

9. Castiglione, J. (2008). Facilitating Employee Creativity In The Library Environment: An Important Managerial Concern for Library Administrators. Library Management, 29, 1938.

10. Csikszentmihalyi, M., \& Wolfe, R. (2005). Conceptions and research approaches to creativity: the implication of a system perspective approach to creativity in education. In K. Heller, F. Mönks, R. Sternberg, \& R. Subotnik (Eds.), International handbook of giftedness and talent (pp. 81-93). Oxford, UK: Elsevier Science Ltd.

11. Darsana, M. (2013). The Influence of Personality and Organizational Culture on Employee Performance Through Organizational Citizenship Behavior. The International Journal Of Management, 2(4), 35-42.

12. Denison, DR (2000). Organizational culture: Can be a key lever for driving organizational change. In S. Cartwright \& C. Cooper (Eds.), The Handbook of Organizational Culture. London: John Wiley \& Sons, Inc.

13. Denison, DR, \& Mishra, KA (1995). Toward A Theory of Organizational Culture and Effectiveness. Journal of Organization Science, 6(2).

14. Dessler, G. (2009). Human Resource Management. Pearson Prentice Hall.

15. Dewwet, T. (2007). Intrinsic Motivation Linking, Risk Taking, And Employee Creativity In An R \& D Environment. R \& D Management, 37(3).

16. Hirst, G., Knippenberg, V., Chen, C.-H., \& Sacramento, CA (2011). How does bureaucracy impact individual creativity? A cross-level investigation of team contextual influences on goal orientation-creativity relationships. Academy of Management Journal, 53(3), 624-641.

17. Indrasari, Meithiana, Newcombe, P., Eliyana, A., \& Yusuf, E. (2015). The Influence Of Academic Climate And Individual Creativity On Lecturer Competence In Private University at Surabaya Indonesia. International Journal of Business and Management, 10(8).

18. Jackson, CJ (2005). An applied neuropsychological model of functional and dysfunctional learning: Applications for business, education, training, and clinical psychology. Retrieved from http://www.cymeon.com/publications/default.asp 
19. Jackson, CJ (2009). Using the hybrid of learning in personality to predict performance in the workplace. In 8th IOP conference (pp. 75-79). Sydney, Australia: Manly.

20. Kanematsu, H., \& Barry, DM (2016). Theory of Creativity. In STEM and ICT Education in Intelligent Environments. (pp. 9-13). Switzerland: Springer International Publishing.

21. Karamipour, MR, Mehraban, M., \& Jahani, S. (2015). The Effect of Organizational Culture on The Employee's Creativity. SAUSSUREA, 3(2), 40-53.

22. Keskin, H. (2009). Learning Orientation and Innovation Capabilities in SMEs. Europe Journal Innovation Management, 9(4), 221-233.

23. Kotter, JP, \& Heskett, JL (1992). Corporate Culture and Performance. New York: Free Press.

24. Kozbelt, A., Beghetto, RA, \& Runco, MA (2010). Theories of Creativity. In JC Kaufman \& RJ Sternberg (Eds.), Cambridge Handbook of Creativity (pp. 20-47). New York: Cambridge University Press.

25. Kreitner, R., \& Kinicki, A. (2012). Organizational Behavior (10th ed.). New York: McGrawHill Higher Education.

26. Latan, H., \& Ghozali, I. (2014). Partial Least Square : Konsep, Metode dan Aplikasi Penggunaan Program WarpPLS 5.0 (Third). Badan Penerbit Universitas Diponegoro.

27. Lee, L.-Y., \& Tan, E. (2012). The Influences Of Antecedents On Employee Performance: A Meta-Analytic Review. Interdisciplinary Journal Of Contemporary Research In Bussiness, 4(2).

28. Mathis, RL, \& Jackson, JH (2010). Human Resource Management (13th ed.). Mason. $\mathrm{OH}$ : South-Western Cengage Learning.

29. Motowidlo, SJ, Borman, WC, \& Schmit, MJ (1997). A theory of individual differences in task and contextual performance. Human Performance, 10(2), 71-83.

30. O'connor, PC, \& Jackson, CJ (2008). Learning to be saint or sinners: The indirect pathway from sensation seeking to behavior through mastery orientation. Journal of Personality, 76, 733-752.

31. Pickering, AD (2004). The neuropsychology of impulsive antisocial sensation-seeking personality traits: From dopamine to hippocampal function. In RM Stelmack (Ed.), On the psychobiology of personality: Essays in honor of Marvin Zuckerman (pp. 454-476). UK: Elsevier.

32. Pothukuchi, V., Damanpour, F., Choi, J., \& Park, SH (2002). National and Organizational Culture Differences and International Joint Venture Performance. Journal of International Business Studies, 33(2), 243-265. https://doi.org/10.1057/palgrave.jibs.8491015

33. Rose, RC, Ramalu, SS, Uli, J., \& Samy, NK (2010). Expatriate Performance in Overseas Assignments: The Role of Big Five Personality. Asian Social Science, 6. https://doi.org/http://dx.doi.org/10.5539/ass.v6n9p104

34. Skyrme, P., Wilkinson, L., Abraham, JD, \& Morrison, JD (2005). Using personality to predict outbound call center job performance. Applied HRM Research, 10(2), 89-98.

35. Sorensen, Jasper B. (2002). The Strength of Corporate Culture and the Reliability of Firm Performance. Administrative Science Quarterly, 47(1), 70-91. https://doi.org/10.2307/3094891

36. Valencia, N., Sanz, R., \& Jimennez, J. (2010). Organization Culture as Determinant of Product Innovation. European Journal of Innovation Management, 13(4), 466-480.

37. Wu, C.-S., Lee, C.-J., \& Tsai, Li-Fen. (2012). Influence Of Creativity And Knowledge Sharing On Performance. Journal of Technology Management in China, 7(1), 64-77. https://doi.org/10.1108/17468771211207358

38. Yang, S.-B., \& Choi, SO (2009). Employee empowerment and team performance: Autonomy, responsibility, information, and creativity. Team Performance Management: An International Journal, 15(5/6), 289-301. https://doi.org/10.1108/13527590910983549

39. Zuckerman, M. (1994). Behavioral Expression and Biosocial bases at sensation seeking. New York: Cambridge University Press. 